\title{
Rumen fermentation and diet degradability in sheep fed sugarcane (Saccharum officinarum) silage supplemented with Tithonia diversifolia or alfalfa (Medicago sativa) and rice polishing
}

\author{
José L. Loya-Olguin ${ }^{\text {a,b* }}$, Esteban Vega-Granados ${ }^{a}$, Agapito Gómez-Gurrola ${ }^{\text {b }}$

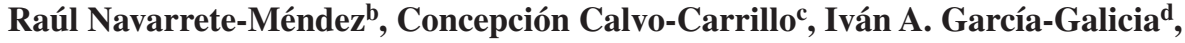 \\ Yissel S. Valdés-García ${ }^{a, b}$, Leonor Sanginés-García ${ }^{c}$
}

\begin{abstract}
The objective of this study was to evaluate ruminal fermentation (i.e. pH, ammonia, and volatile fatty acid concentrations) and in situ degradability of diets in sheep fed sugarcane silage (SCS) supplemented with Tithonia diversifolia (Td) or alfalfa (Medicago sativa) hay (A), with or without rice (Oriza sativa) polishing (RP) as an energy source. Four Blackbelly sheep (35 kg average body weight) with rumen cannula were used. The experimental diets were ( $\mathrm{g} / \mathrm{kg}$ of dry matter): Diet 1) SCS (686) + Td (294), Diet 2) SCS (460) + Td (226) + RP (294), Diet 3) SCS (637) + A (343), and Diet 4) SCS (441) + A (245) + RP (294). The remainder $(20 \mathrm{~g} / \mathrm{kg}$ of dry matter) was composed by minerals supplement and salt. Samples of diets were incubated into rumen for 3 , $6,9,12,24,30,36,48$, and $72 \mathrm{~h}$ to determine in situ degradability. Data were analysed with a linear mixed model. The lamb, period and lamb nested in period*diet were considered as a random variable. The inclusion of RP improved the degradability of diets and ammonia production in the rumen. The acetic, propionic, and butyric acid concentrations $(\mathrm{mmol} / 100 \mathrm{~mL})$ in rumen increased $(P<0.03)$ when diets with alfalfa and RP were provided. The degradability of diets based on sugarcane silage supplemented with either alfalfa or Tithonia diversifolia was improved $(P<0.05)$ with the rice polishing inclusion, with no difference $(P>0.05)$ between these forages. In conclusion, energy supplementation, not necessarily from starch, is important to improve rumen fermentation and degradability of diets based on sugarcane silage.

Key words: ammonia, energy, forage, protein.
\end{abstract}

\section{INTRODUCTION}

Sugarcane (Saccharum officinarum) is an important forage in the tropics because of its great biomass and energy production and low cost per ton of dry matter. Moreover, its harvest coincides with the dry season, and its conservation by ensiling could be an important contribution towards improving animal production in tropical regions (Santos da Silva et al 2014). Sugarcane silage could be an alternative forage for use at times when the quality and growth of grasses are poor (Montañez-Valdez et al 2013). Sugarcane silage contains a high concentration of soluble carbohydrates (Pedroso et al 2005, Sousa et al 2017), but low protein quality and low digestibility of fibre. Digestibility and intake of forage poor in nitrogen (N) can be improved by supplementation with Tithonia diversifolia (Td) (Wambui et al 2006 ${ }^{\mathrm{a}}$ ), which is a shrub native to Mexico and widely distributed in the humid

Received: 23.09.2019.

Accepted: 19.03.2020

aposgrado en Ciencias Biológico Agropecuarias, Universidad Autónoma de Nayarit, Nayarit, México.

bUnidad Académica de Medicina Veterinaria y Zootecnia, Universidad Autónoma de Nayarit, Nayarit, México.

'Departamento de Nutrición Animal, Instituto Nacional de Ciencias Médicas y Nutrición Salvador Zubirán, Ciudad de México, México.

${ }^{\mathrm{d}}$ Facultad de Zootecnia y Ecología, Universidad Autónoma de Chihuahua, Chihuahua, México.

*Corresponding author: JL Loya-Olguin; Tepic, Nayarit, México, CP 63023; joselenin28@hotmail.com tropics and sub-humid areas of Central and South America (Jama et al 2000). This shrub has been shown to undergo significant leaf production (Wuambui et al 2006 ${ }^{\mathrm{b}}$ ) and vigorous regrowth after cutting (Ramírez-Rivera et al $2010)$ and has elevated crude protein content $(\sim 20 \%)$ as well (Kayuki and Wortmann 2001, Wuambui et al 2006 ${ }^{\mathrm{a}}$ ). The soluble protein content of its foliage accounts for $40 \%$ of its total protein content (Ramirez-Rivera et al 2010), and the potential utilisation of this soluble protein by cattle can be increased by the soluble carbohydrates of sugarcane silage.

The synchrony of rumen degradable protein (RDP) and fermentable metabolisable energy (FME) concentration in animal diets influence microbial protein yield and animal productivity (López-Soto et al 2014). Therefore, the importance of using by-products that increase the energy available to the silages-based diets enriched with high-protein forages is relevant. Rice polish is a by-product of the rice milling industry and is derived from the outer layers of the rice caryopsis during milling. It consists of pericarp, seed coat, nucleus, aleurone layer, germ and part of the sub-aleurone layer of starchy endosperm (Juliano 1988). For the above, rice polish contains similar metabolisable energy compared with that of grains such as corn or sorghum (NRC 2007, Hossain et al 2012), and have a lower price than those grains; thus, rice polish may be used as an energy supplement in diets based on silages combined with high-protein forages. However, the energy of this by-product comes from a different source compared with other by-products (i.e. molasses) because of its elevated protein and lipid content (NRC 2007, Salinas-Chavira et al 2008). 
To our knowledge, there are no published studies that directly assess the rice polishing as an energy source of silage-based diets enriched with high protein forage sources. Hence, the aim of the study was to determine if diets based on sugarcane silage supplemented with Tithonia diversifolia (Td) or Medicago sativa (alfalfa, A), as a source of protein, and with rice polishing (RP) as a source of fat-derived energy, could improve the ruminal degradation and fermentation. Hypothetically rice polishing used as an energy supplement in diets based on sugar cane silage combined with high-protein forages would improve rumen fermentation and degradability because of complementation with rumen degradable protein and fermentable metabolisable energy of these diets.

\section{MATERIAL AND METHODS}

Experimental trials were conducted at the Universidad Autónoma de Nayarit (UAN) in Compostela, Nayarit, Mexico (21 ${ }^{\circ} 17^{\prime} 46^{\prime \prime} \mathrm{N}, 104^{\circ} 54^{\prime} 00^{\prime \prime} \mathrm{W}$, and 880 masl) where the predominant climatic conditions correspond to sub-humid tropical type, with a mean temperature of $22{ }^{\circ} \mathrm{C}$, rainfall mainly in the summer, and total annual precipitation of $1,000 \mathrm{~mm}$.

Animal management procedures were conducted following the guidelines officially-approved, NOM (Norma Oficial Mexicana), for animal use and care (NOM051-ZOO-1995: humanitarian care of animals during mobilisation of animals; NOM-062-ZOO-1999: technical specifications for the care and use of laboratory animals).

\section{ANIMALS AND TREATMENTS}

Four uncastrated Blackbelly rams $(35 \pm 1.2 \mathrm{~kg}$ body weight, BW) fitted with cannulas in the rumen were used in a $4 \times 4$ Latin square design with 21 -d periods for adaptation and sampling. The animals were housed in individual pens of $60 \times 180 \mathrm{~cm}$ with steel mesh flooring and individual feeders and drinkers. The sheep were treated for internal and external parasites with ivermectin ( $200 \mu \mathrm{g} / \mathrm{kg} \mathrm{BW}$; SC).

Four experimental diets were formulated to meet the nutritional requirements for growing sheep $(147 \mathrm{~g} / \mathrm{kg} \mathrm{CP}$ and 3.2 Mcal $/ \mathrm{kg} \mathrm{DE}$ ) according to the NRC (1985) and were randomly assigned to each animal. The diets were isocaloric and isoproteic, and were based on sugarcane silage supplemented with either Tithonia diversifolia or alfalfa, with or without rice polishing. The Tithonia diversifolia forage was harvested at the UAN $60 \mathrm{~d}$ after the last cut, chopped to obtain $2-3 \mathrm{~cm}$ particle size and sun dried for $72 \mathrm{~h}$ and turned every $24 \mathrm{~h}$. Alfalfa hay and rice polishing were purchased at a commercial establishment. Sugarcane silage was prepared using the entire plant (harvested $24 \mathrm{~m}$ after sowing), chopped up into $3-5 \mathrm{~cm}$ pieces. An inoculum prepared with sugarcane molasses $(10 \%)$, urea $(0.5 \%)$, chicken manure $(5 \%)$, yoghurt $(1 \%)$, and water $(83.5 \%)$ was added to the fresh forage at a level of 3\% (Reyes-Gutierrez et al 2012). Also, urea (1.0\%), ammonium sulfate $(0.1 \%)$, and diammonium phosphate $(0.25 \%)$ were added by spraying it on each layer of sugarcane during ensiling. The forage was compacted with 4 passes of the Massey Ferguson tractor of 3.5 tons of weight. Once compacted, the forage was covered with plastic and a layer of $10-15 \mathrm{~cm}$ of dust on top until silage was used three months later.

The experiment lasted $84 \mathrm{~d}$ divided into four experimental periods of $21 \mathrm{~d}$ each, consisting of first $14 \mathrm{~d}$ for diet adaptation, followed by $7 \mathrm{~d}$ for rumen fluid sample collection and determination of the kinetics of disappearance of dry matter. During the adaptation period, the feed was offered in amounts $110 \%$ of that consumed the previous day, so that sheep had ad libitum access to feed. During the sample collection period, sheep received $90 \%$ of the amount of feed previously consumed ad libitum to avoid refusals. Each animal received a different experimental diet in each period. On the fifteenth day of each period, rumen content samples (approximately $100 \mathrm{~mL}$ ) was obtained from each lamb at $0,3,6,9$, and $12 \mathrm{~h}$ after feeding via the ruminal cannula. Ruminal samples were manually taken from different sites of the rumen. Ruminal content $\mathrm{pH}$ was immediately determined on fresh samples with a portable pH meter (Horiba, Ltd.). Following pH determination, a sample of rumen fluid was obtained through filtering rumen content sample with four layers of cheesecloth. Two $\mathrm{mL}$ of freshly prepared $25 \%(\mathrm{w} / \mathrm{v})$ meta-phosphoric acid was added to $8 \mathrm{~mL}$ of strained ruminal fluid. Samples were centrifuged $(17,000 \times \mathrm{g}$ for $10 \mathrm{~min})$ and the supernatant fluid was stored at $-20^{\circ} \mathrm{C}$ for VFA analysis (Erwin et al 1969). For ammonia nitrogen $\left(\mathrm{NH}_{3}-\mathrm{N}\right)$ analysis, $10 \mathrm{~mL}$ of strained ruminal fluid was acidified with $0.5 \mathrm{~mL}$ of 6 $\mathrm{N} \mathrm{HCl}$ and was stored at $-20{ }^{\circ} \mathrm{C}$ for $\mathrm{N}-\mathrm{NH}_{3}$ determination (Godeau et al 1987).

On the $18^{\text {th }}$ day of each period, the ruminal degradation of diets was determined using nylon bags (Diammod bar®) with rounded corners. They were $10 \times 15 \mathrm{~cm}$ in size with a pore size of $50-\mu \mathrm{m}$. Diet samples were oven-dried at $60^{\circ} \mathrm{C}$ for $48 \mathrm{~h}$, and were ground to pass through a $2 \mathrm{~mm}$ screen (Wiley® mill). Five grams of diet sample were placed in each bag. Two bags per diet, animal and time were prepared. Bags with sample were placed into the rumen tying them to a chain with a polyester cord at $3,6,9,12$, $24,30,36,48,56$, and $72 \mathrm{~h}$ post-feeding. After retrieval, of all bags at the same time were manually rinsed under running water until the wash water was clear, dried in a forced-air oven at $65^{\circ} \mathrm{C}$ for $48 \mathrm{~h}$ and then weighed. The same procedure was applied to bags without rumen incubation $(0 \mathrm{~h})$. Rumen dry matter (DM) disappearance was estimated using a model of first-order kinetics proposed by Waldo et al (1972). The NEWWAY software (Rowett Research Institute) was used to fit data obtained from the DM degradation estimates to the equation $\mathrm{Y}=\mathrm{a}+\mathrm{b}$ $\left(1-\mathrm{e}^{\mathrm{ct}}\right)$ for kinetic degradation (Orskov and McDonald, 1979), where $\mathrm{Y}$ is the DM degradation at time $t$, $\mathrm{a}$ is the 
soluble fraction, $\mathrm{b}$ is the potentially degradable insoluble fraction, $\mathrm{c}$ is the rate of degradation, and $\mathrm{t}$ is the time.

\section{STATISTICAL ANALYSIS}

Experimental data (ruminal $\mathrm{pH}, \mathrm{NH}_{3}-\mathrm{N}, \mathrm{VFA}$ and $\mathrm{pH}$ ) were analyzed using a linear mixed model for repeated measurements (SAS 2007, version 9.1). The sheep, period and the interaction sheep*period*diet was considered as a random variable. The hour of sampling was considered as a repeated measurement. The model adjusted was as described below.

$$
\begin{gathered}
\mathrm{Y}_{\mathrm{ijkl}}=\mu+\mathrm{D}_{\mathrm{i}}+\mathrm{T}_{\mathrm{j}}+(\mathrm{D} * \mathrm{~T})_{\mathrm{k}}+(\mathrm{D} * \mathrm{~T} 2)_{1}+(\mathrm{D} * \mathrm{~T} 3)_{\mathrm{m}} \\
+(\mathrm{S} / \mathrm{D} * \mathrm{~T})_{\mathrm{n}}+\varepsilon_{\mathrm{ijklmn}}
\end{gathered}
$$

Where $\mu$ is the overall mean, $\mathrm{Dk}$ is the effect of the ith diet, $\mathrm{Tj}$ is the effect of the lth time after feeding $(0,3$, $6,9$ and $12 \mathrm{~h}),\left(\mathrm{D}^{*} \mathrm{~T}\right)_{\mathrm{k}}$ is the effect of the kth interaction, (D*T2) is the effect of the lth interaction of diet and quadratic time, $(\mathrm{D} * \mathrm{~T} 3)_{\mathrm{m}}$ is the effect of the $\mathrm{mth}$ interaction of diet and cubic time, $(\mathrm{S} / \mathrm{D} * \mathrm{~T})_{\mathrm{n}}$ is the random effect of the animal nested in diet * period of sampling, and cijklmn is the residual term. Time after feeding was considered as a repeated measurement with an autoregressive covariance structure. When a significant difference was detected, treatment means were compared with the Tukey test $(P<0.05)$.

\section{RESULTS AND DISCUSSION}

The soluble fraction was similar $(P>0.05)$ among the experimental diets. The potential of degradation and the percentage of insoluble but potentially degradable fraction was increased $(P<0.05)$ by the inclusion of rice polishing, with no difference $(P>0.05)$ between the diet with Tithonia diversifolia and alfalfa (table 1). The potential of degradation $(a+b)$ of diets without rice polishing in this study was around those observed (57.2\%) by Montañez-Valdez et al
(2013) for ensiled sugarcane without supplementation, but were up to $74 \%$ greater with the addition of rice polishing. This finding can be explained by the greater insoluble but degradable fraction of diets with rice polishing. Although the in situ degradation of diets has been shown to be improved with Tithonia diversifolia inclusion (Premaratne et al 1997, Naranjo and Cuartas 2011), according to these results the benefits of protein provided by forages, such as those used in the present study, can be useful if energy is available from ingredients such as rice polishing.

The ruminal $\mathrm{pH}$ values declined $(P<0.05)$ at $3 \mathrm{~h}$ after feeding with all diets. In addition, differences were detected at 6 and $9 \mathrm{~h}$ in which values with Diet 4 were lower $(P<0.05)$ compared to Diet 1 . The $\mathrm{pH}$ decline at 3 $\mathrm{h}$ post-feeding on all experimental diets reflects the time at which fermentation occurred (figure 1). The highest $\mathrm{pH}$ values observed for the diet with Tithonia diversifolia without rice polishing may be explained its NDF content (53\%), which implies slower digestion. The average $\mathrm{pH}$ range (6.14-6.88) of the rumen observed on all experimental diets was within the normal range (6-7) for microbial fibre digestion and corresponds to that observed for forage-based diets with high percentages of cellulose and hemicellulose (Krause et al 2002).

Ruminal $\mathrm{NH}_{3}-\mathrm{N}$ concentration increased $(P<0.05)$ at $3 \mathrm{~h}$ with Diet 1 and Diet 4 , and decreased $(P<0.05)$ at $9 \mathrm{~h}$ compared to $3 \mathrm{~h}$ post-feeding with rice polishing addition (figure 2). Therefore, the rice polishing addition increased the production and absorption of $\mathrm{NH}_{3}-\mathrm{N}$. Vega et al (2019) observed greater intake, retention and absorption of $\mathrm{N}$ with rice polishing addition. The $\mathrm{NH}_{3}-\mathrm{N}$ increase after 3 $\mathrm{h}$ post-feeding agrees with a study by Nolan (1993). After the peak, however, $\mathrm{NH}_{3}-\mathrm{N}$ concentration decreased with all diets, which is similar to findings of Benedeti et al (2014), who observed lower concentrations of $\mathrm{NH}_{3}-\mathrm{N} 10 \mathrm{~h}$ after feeding. However, the concentration decline was quite pronounced in diets with rice polishing, perhaps because the higher energy availability of these diets led to $\mathrm{NH}_{3}-\mathrm{N}$

\begin{tabular}{|c|c|c|c|c|c|}
\hline Item & $\mathrm{RP}, \% / \mathrm{h}^{\dagger}$ & Diet 1 & Diet 2 & Diet 3 & Diet 4 \\
\hline$a^{\mathbb{I I}}$ & & $20.7 \pm 4.2$ & $26.4 \pm 2$ & $24.9 \pm 6.4$ & $20.2 \pm 8.1$ \\
\hline $\mathrm{b}$ पI II & & $31.5 \pm 3.3^{\mathrm{b}}$ & $52.5 \pm 4.7^{\mathrm{a}}$ & $35.6 \pm 6.6^{\mathrm{b}}$ & $54.1 \pm 4.1^{\mathrm{a}}$ \\
\hline$c^{\S}$ & & $0.06 \pm 0.03^{\mathrm{a}}$ & $0.05 \pm 0.01^{\mathrm{a}}$ & $0.032 \pm 0.02^{\mathrm{b}}$ & $0.05 \pm 0.01^{\mathrm{b}}$ \\
\hline Zero time, $\%$ & & $12.4 \pm 6.4$ & $16.95 \pm 4.8$ & $13.9 \pm 7.3$ & $10.1 \pm 7.3$ \\
\hline $\mathrm{PD}, \%^{\mathrm{P}}$ & & $52.10 \pm 4.5^{\mathrm{b}}$ & $78.9 \pm 3.8^{\mathrm{a}}$ & $60.5 \pm 8.1^{\mathrm{b}}$ & $74.3 \pm 8.03^{\mathrm{a}}$ \\
\hline $\mathrm{ED}, \%^{\mathrm{P} \mathrm{P}}$ & 2 & $44.4 \pm 5.2^{b}$ & $70.2 \pm 2.3^{\mathrm{a}}$ & $45.6 \pm 1.5^{\mathrm{b}}$ & $68.8 \pm 7.8^{\mathrm{a}}$ \\
\hline $\mathrm{ED}, \%^{\mathrm{P} \mathrm{P}}$ & 5 & $38.2 \pm 3.1^{\mathrm{b}}$ & $58.1 \pm 1.4^{\mathrm{a}}$ & $37.4 \pm 0.7^{b}$ & $57.2 \pm 7.8^{\mathrm{a}}$ \\
\hline $\mathrm{ED}, \%^{\mathrm{P} P}$ & 8 & $34.4 \pm 3.1^{\mathrm{b}}$ & $51.5 \pm 1.03^{\mathrm{a}}$ & $34.2 \pm 1.1^{\mathrm{b}}$ & $47.2 \pm 7.8^{\mathrm{a}}$ \\
\hline
\end{tabular}

Table 1. In situ kinetics of dry matter digestibility ( \pm SEM) of the experimental diets.

\footnotetext{
a,b Means with different letter in a row are statistically different (Tukey, $P<0.05$ ), SEM: standard error of the mean, Diet 1: sugar cane silage + Tithonia diversifolia, Diet 2: sugar cane silage + Tithonia diversifolia + rice polishing, Diet 3: sugar cane silage + alfalfa, Diet 4: sugar cane silage + alfalfa + rice polishing. ${ }^{\dagger}$ Rate of passage. ${ }^{\mathbb{T}}$ S Soluble fraction (\%). ${ }^{\text {II I }}$ Potentially degradable insoluble fraction (\%). ${ }^{{ }}$Rate of degradation $\left(\mathrm{h}^{-1}\right) .{ }^{\mathrm{P}}$ Potential degradability. ${ }^{\text {P P }}$ Effective degradability.
} 

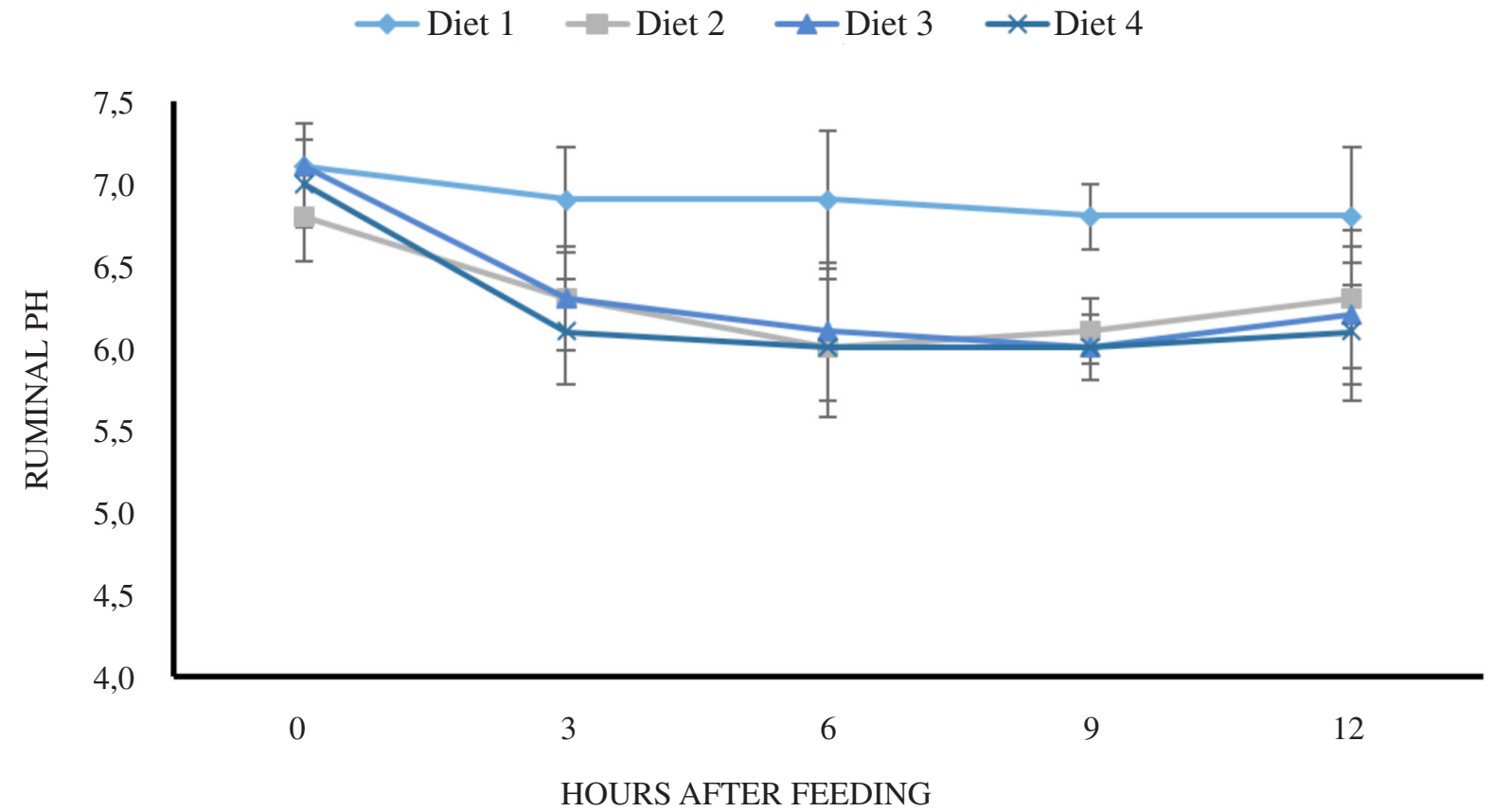

Figure 1. Ruminal $\mathrm{pH}$ of animals fed with sugarcane silage supplemented with Tithonia diversifolia or alfalfa, with or without rice polishing at different times (hours after feeding). Diet 1: sugar cane silage + Tithonia diversifolia, Diet 2: sugar cane silage + Tithonia diversifolia +rice polishing, Diet 3: sugar cane silage + alfalfa, Diet 4: sugar cane silage + alfalfa + rice polishing.

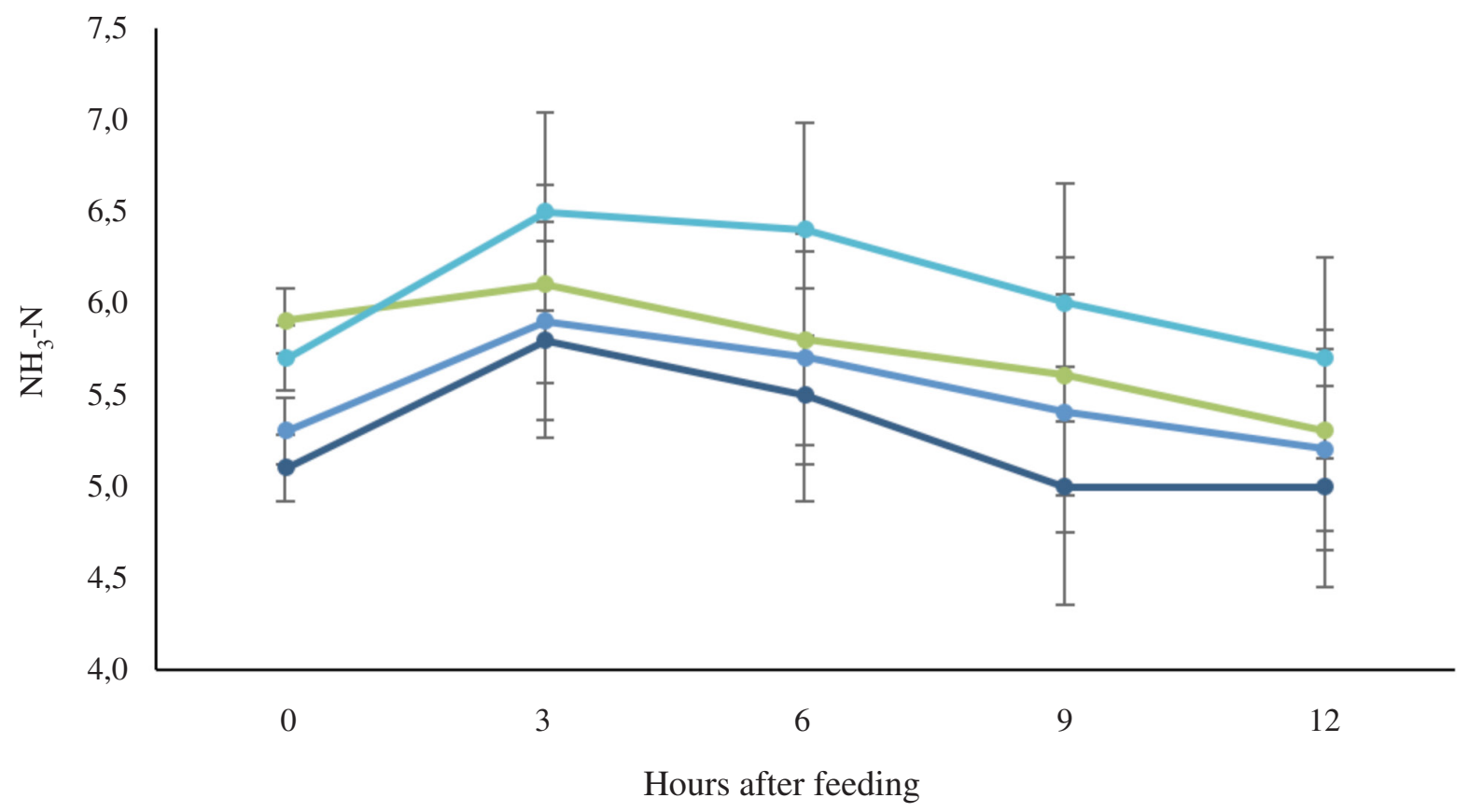

$\multimap$ Diet $1 \quad \longrightarrow$ Diet $2 \quad$ Diet $3 \quad$ Diet 4

Figure 2. Ammonia- $\mathrm{N}(\mathrm{mg} / 100 \mathrm{~mL})$ concentrations in the rumen of animals fed with sugarcane silage supplemented with Tithonia diversifolia or alfalfa, with or without rice polishing at different times (hours after feeding). Diet 1: sugar cane silage + Tithonia diversifolia, Diet 2: sugar cane silage + Tithonia diversifolia + rice polishing, Diet 3: sugar cane silage + alfalfa, Diet 4: sugar cane silage + alfalfa + rice polishing. 


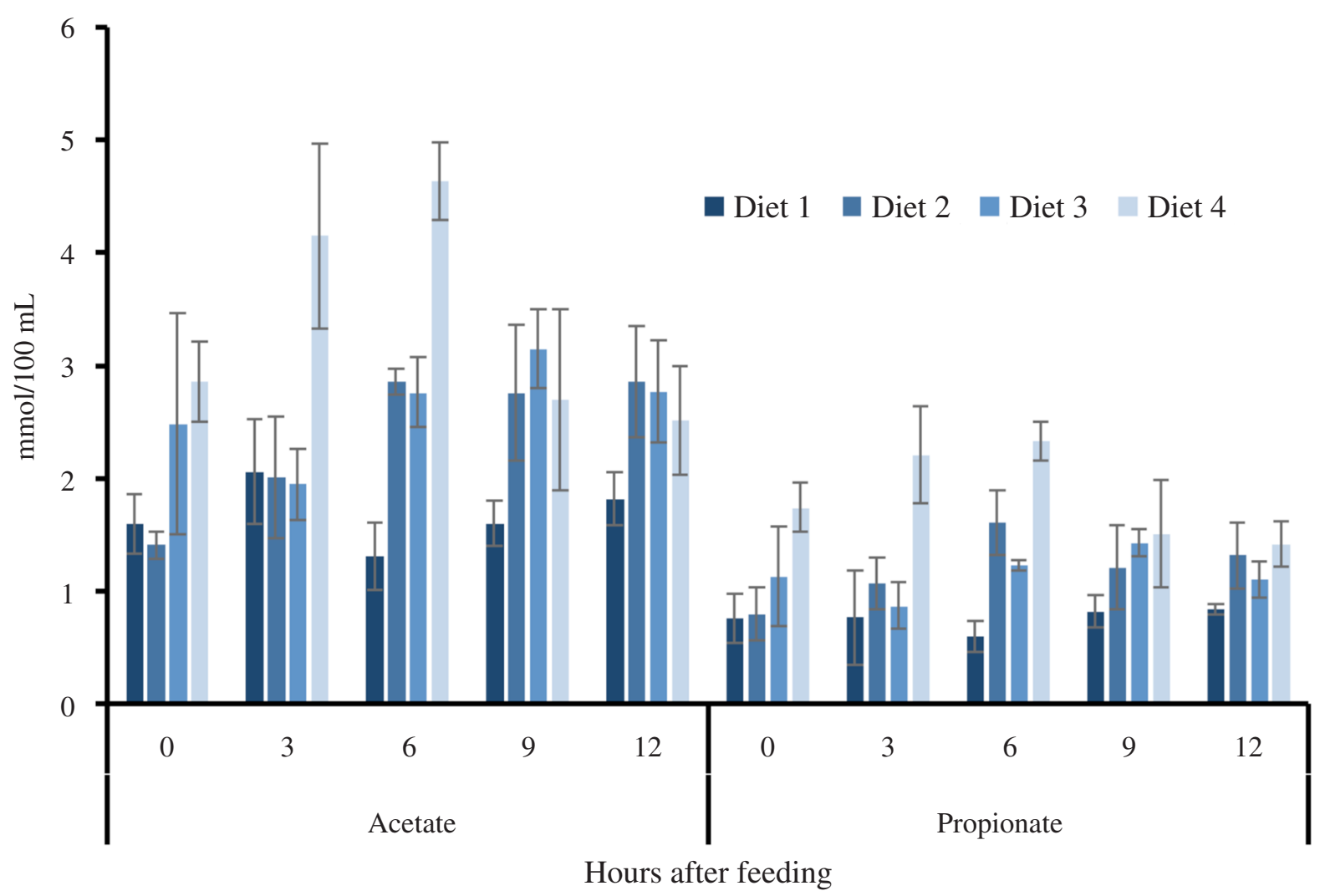

Figure 3. Acetate and propionate $(\mathrm{mmol} / 100 \mathrm{~mL})$ concentrations of animals $(\mathrm{n}=4)$ fed with sugarcane silage supplemented with $T i$ thonia diversifolia or alfalfa, with or without rice polishing at different times (hours after feeding). Diet 1: sugar cane silage + Tithonia diversifolia, Diet 2: sugar cane silage + Tithonia diversifolia + rice polishing, Diet 3: sugar cane silage + alfalfa, Diet 4: sugar cane silage + alfalfa + rice polishing.

assimilation by rumen microorganisms (Benedeti et al 2014). Similarly, Bailey et al (2012) observed an increase in ruminal $\mathrm{NH}_{3}-\mathrm{N}$ between 2 and $10 \mathrm{~h}$ after high levels of casein supplementation to steers consuming low-quality forage (5.8\% CP and 71\% NDF), but not in those steers with lower levels of casein and glucose supplementation.

Rice polishing and alfalfa (Diet 4) addition increased $(P<0.05)$ ruminal concentration of acetate, propionate, butyrate and valerate and decreased isovalerate at 3 and $12 \mathrm{~h}$ post-feeding, respectively. Inclusion of rice polishing in diets increased $(P<0.05)$ the concentration of acetate, propionate, butyrate, and isovalerate between 3 and $9 \mathrm{~h}$ post-feeding.

Fibrous carbohydrates in diets elevate acetate production (Lins et al 2016), but this requires elevated energy and protein as well. Starch content of diets enhances the development of propionate-producing bacteria and, consequently, propionate production at the expense of acetate (France and Siddons 1993). Bailey et al (2012) observed greater ruminal acetate concentration with casein and protein supplementation. The lowest concentration of isovaleric acid at $12 \mathrm{~h}$ (figure 4) observed in this study with the diet of alfalfa supplemented with rice polishing may have been due to the utilisation of this acid by rumen bacteria to improve fermentation, which was reflected in the greatest concentration of acetate at this point.

Protein may be important as a source of VFA when diets are rich in rumen-degradable protein (France and Siddons 1993). Protein fermentation could generate high amounts of branched-chain fatty acids (Dijkstra 1994). France and Siddons (1993) showed that increases in valerate, isovalerate, and isobutyrate stimulated cellulose digestion. VFA concentration is positively related to ruminal $\mathrm{NH}_{3}-\mathrm{N}$ (Wanapat and Pimpa 1999). Adequate $\mathrm{NH}_{3}-\mathrm{N}$ concentration for ruminal microorganism growth with no effect on VFA production may indicate energy deficiency or asynchrony of the availability of $\mathrm{N}$ and energy, or both.

In conclusion, rumen fermentation and degradability of sugarcane silage-diets with Tithonia diversifolia or alfalfa were enhanced by the inclusion of rice polishing. Rice polishing improved the utilisation of the $\mathrm{NH}_{3}-\mathrm{N}$. Therefore, energy, not exclusively from starch, is important to take advantage of the forage protein to improve rumen fermentation of diets based on sugarcane silage. 

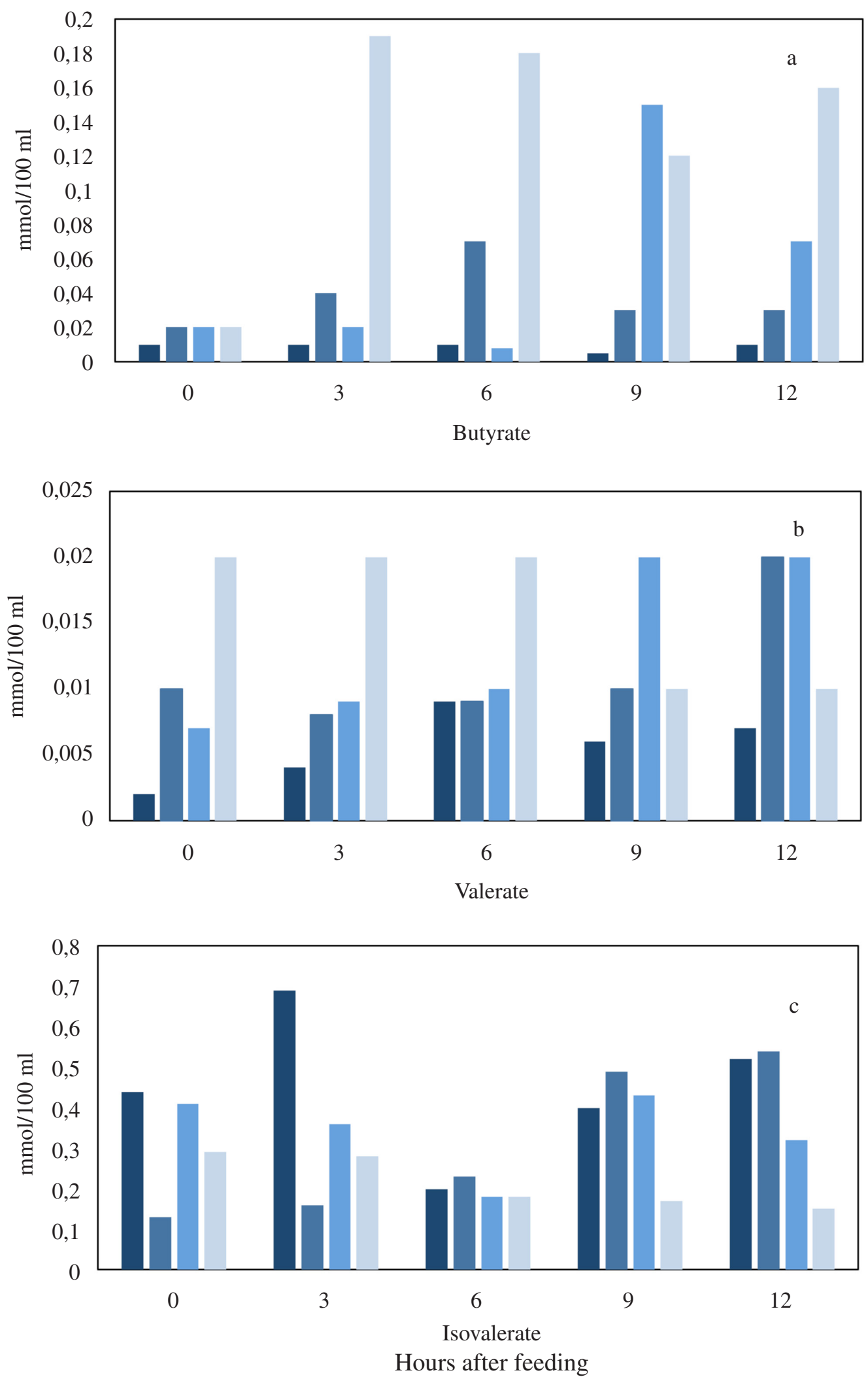

-Diet $1 \quad \square$ Diet $2 \square \operatorname{Diet} 3 \backsim \operatorname{Diet} 4$

Figure 4. Butyric (a), valeric (b) and isovaleric (c) acids $(\mathrm{mmol} / 100 \mathrm{~mL})$ concentrations in sheep $(\mathrm{n}=4)$ fed with sugarcane silage supplemented with Tithonia diversifolia or alfalfa, with or without rice polishing at different times (hours after feeding). Diet 1: sugar cane silage + Tithonia diversifolia, Diet 2: Sugar cane silage + Tithonia diversifolia + rice polishing, Diet 3: Sugar cane silage + alfalfa, Diet 4: Sugar cane silage + alfalfa + rice polishing. 


\section{REFERENCES}

AOAC, Association of Official Analytical Chemistry. 2000. Official Methods of Analysis. 17 ${ }^{\text {th }}$ ed. Gaithersburg, MD, USA.

Bailey EA, Titgemeyer EC, Olson KC, Brake DW, Jones ML, et al. 2012. Effects of supplemental energy and protein on forage digestion and urea kinetics in growing beef cattle. J Anim Sci 90, 3492-3504.

Benedeti PDB, Paulino PVR, Marcondes MI, Valadares Filho SC, Martins TS, et al. 2014. Soybean meal replaced by slow release urea in finishing diets for beef cattle. Livest Sci 165, 51-60.

Dijkstra J. 1994. Production and absorption of volatile fatty acids in the rumen. Livest Prod Sci 39, 61-69.

Erwin ES, Marco JG, Emery EM. 1969. Volatile fatty acid analysis of blood and rumen fluid by gas chromatography. J Dairy Sci 44, 1768-1771.

France J, Siddons RC. 1993. Volatile fatty acid production. In: Forbes $\mathrm{JM}$, France J (eds). Quantitative aspects of ruminant digestion and metabolism. CAB International, Wallingford, United Kingdom, Pp 107-121.

Godeau JM, Gillet Y, Teller E, De Dryver G. 1987. Recyclage d'azote endogene par le rumen en période de jeûne chez la vache tarie. Ann Med Vet 131, 113-122.

Goering HK, Van Soest PJ. 1970. Forage Fiber analyses (apparatus, reagents, procedures, and some applications). Agricultural Handbook 379, ARS-USDA, Washington, DC, USA.

Hossain ME, Sultana S, Shahriar SMS, Khatun MM. 2012. Nutritive value of rice polish. Online J Anim Feed Res 2, 235-239.

Jama, B, Palm CA, Buresh RJ, Niang A, Gachengo C, et al. 2000. Tithonia diversifolia as a green manure for soil fertility improvement in western Kenya: A review. Agroforest Syst 49, 201-221.

Juliano BO. 1988. Rice bran. In: Houston DF (ed). Rice chemistry and technology. American Association of Cereal Chemists, St Paul, Minnesota, USA, Pp 647-687.

Kayuki KC, Wortmann CS. 2001. Plant materials for soil fertility management in subhumid tropical areas. Agron J 93, 929-935.

Krause KM, Combs DK, Beauchemin KA. 2002. Effects of forage particle size and grain fermentability in midlactation cows. II. Ruminal $\mathrm{pH}$ and chewing activity. J Dairy Sci 85, 1947-1957.

Lins SEB, Pessoa RAS, Ferreira MA, Campos JMS, Silva JABA, et al. 2016. Spineless cactus as a replacement for wheat bran in sugar canebased diets for sheep: intake, digestibility, and ruminal parameters. Rev Bras Zootecn 45, 26-31.

López-Soto MA, Rivera-Méndez CR, Aguilar-Hernández JA, Barreras A, Calderón-Cortés JF, et al. 2014. Effects of combining feed grade urea and a slow-release urea product on characteristics of digestion, microbial protein synthesis and digestible energy in steers fed diets with different starch:ADF ratios. Asian Austral. J Anim Sci 27, 187-193.

Montañez-Valdez OD, Reyes-Gutiérrez JA, Guerra-Medina CE, AbdelFattah ZMS. 2013. Rumen dry matter degradability of fresh and ensiled sugarcane. Afri J Biotechnol 12, 2743-2747.

Naranjo JF, Cuartas CA. 2011. Caracterización nutricional y de la cinética de degradación ruminal de algunos de los recursos forrajeros con potencial para la suplementación de rumiantes en el trópico alto de Colombia. Rev CES Med Vet Zootecn 6, 9-19.

Nolan JV. 1993. Nitrogen kinetics. In: Forbes JM, France J (eds). Quantitative Aspects of ruminant digestion and metabolism. CAB International, Wallingford, United Kingdom, Pp 123-143.
NRC, National Research Council. 1985. Nutrient requirements of sheep. The National Academy Press, Washington, DC, USA.

NRC, National Research Council. 2007. Nutrient Requirements of Small Ruminants (sheep, goats, cervids, and new world camelids). The National Academy Press, Washington, DC, USA.

Orskov ER, McDonald I. 1979. The estimation of protein degradability in the rumen from incubation measurements weighted according to rate of passage. J Agric Sci 92, 499.

Orskov ER. 1999. Supplement strategies for ruminants and management of feeding to maximize utilization of roughages. Prev Vet Med 38, 179-185

Pedroso AF, Nussio LG, Paziani SF, Loures DRS, Igarasi MS, et al. 2005. Fermentation and epiphytic microflora dynamics in sugarcane silage. Sci Agr 62, 427-432.

Premaratne S, Bruchem J, Perera HGD. 1997. Effects of type and level of forage supplementation on voluntary intake, and digestibility of rice straw in sheep. Asian Austral J Anim Sci 10, 226-228.

Ramírez-Rivera U, Sanginés GR, Escobedo MJ, Cen CF, Rivera LJ, et al. 2010. Effect of diet inclusion of Tithonia diversifolia on feed intake, digestibility and nitrogen balance in tropical sheep. Agroforest Syst 80, 295-302.

Reyes-Gutierrez JA, Montañez-Valdez OD, Rodríguez-Macias R, RuízLopez MA, Salcedo-Perez E, et al. 2012. Efecto de la adición de inóculo y aditivo en la digestibilidad in situ de la materia seca del ensilado de caña de azúcar. Cienc Tecnol 5, 13-16.

Salinas-Chavira J, Guerrero VI, Robles CA, Montaño-Gómez MF, Montañez-Valdez OD. 2008. Effect of tallow and rice polishings in feedlot rations on growth and carcass characteristics of lambs. $J$ Appl Anim Res 34, 45-48.

Santos da Silva W, Carvalho dos Santos TM, Cavalcanti Neto CC, Espíndola Filho AM, Mesquita da Silva SG, et al. 2014. Características y estabilidad aeróbica de ensilajes de caña de azúcar, tratada con urea, $\mathrm{NaOH}$ y maíz. Pastos y Forrajes 37, 182-190.

SAS, Statistical Analysis System. 2007. SAS/STAT 9.1 User's Guide. SAS Institute Inc., Cary, NC, USA.

Sousa DO, Mesquita B, Pires AV, Santana M, Silva L. 2017. Effects of fibre digestibility and level of roughage on performance and rumen fermentation of finishing beef cattle. Trop Anim Health Prod 49, 1503-1510.

Vega GE, Sanginés GL, Gómez GA, Hernández-Ballesteros A, Solano L, et al. 2019. Replacement of alfalfa with Tithonia diversifolia in lambs fed sugar cane silage-based diets and rice polishing. Rev Mex Cienc Pecu 10, 267-282.

Waldo DR, Smith LW, Cox EL. 1972. Models of cellulose disappearance from the rumen. J Dairy Sci 55, 125-129.

Wambui CC, Abdulrazak SA, Noordin Q. 2006 . Performance of growing goats fed urea sprayed maize stover and supplemented with graded levels of Tithonia diversifolia. Asian Austral J Anim Sci 19, 992-996.

Wambui CC, Abdulrazak SA, Noordin Q. 2006 ${ }^{\mathrm{b}}$. Performance of growing goats fed urea sprayed maize stover and supplemented with graded levels of Tithonia diversifolia. Asian Austral J Anim Sci 19, 992-996.

Wanapat M, Pimpa O. 1999. Effect of ruminal NH3-N levels on ruminal fermentation, purine derivatives, digestibility and rice straw intake in swamp buffaloes. Asian Austral. J Anim Sci 12, 904-907. 
